\title{
DESAIN PETRI NET DAN ALJABAR MAX-PLUS PADA SISTEM PRODUKSI SOYGHURT SUSU BERKAH
}

\author{
Dewi Nurmalitasari ${ }^{1 *}$, Ratna Eka Iswahyuni ${ }^{2}$ \\ ${ }^{1,2}$ Program Studi Pendidikan Matematika, STKIP PGRI Pasuruan \\ 1*dewinurmalitasari31@gmail.com
}

\begin{abstract}
Abstrak
Pembuatan soyghurt masih tergolong baru yang dikembangkan oleh beberapa orang di Indonesia sehingga masih terdapat kendala pada sistem produksinya yaitu kendala estimasi waktu proses produksi dari awal hingga akhir dan ketika produksi dilakukan berulang kali. Tujuan dari penelitian ini adalah untuk memperoleh desain dari alur Petri Net yang dibuat dapat ditentukan nilai estimasi waktu pada sistem produksi soyghurt menggunakan Aljabar Max-Plus sehingga pemilik usaha dapat mengoptimalkan jumlah produksi berdasarkan waktu estimasi tersebut. Hasil penelitian menunjukkan bahwa desain Petri Net yang dibuat tidak mengalami deadlock atau liveness, dan diperoleh estimasi waktu jika produksi dimulai pukul 06.00 maka selesai produksi yaitu 00.10.
\end{abstract}

Kata Kunci: aljabar max-plus, petri net, produksi soyghurt

\section{Abstract:}

Making Soyghurt is still relatively new which was developed by several people in Indonesia so that there are still obstacles in the estimated time of production from the beginning to the end of production. The purpose of this research is to obtain a Petri Net design from the plot created and determine the estimated time using Max-Plus Algebra. The results showed that the Petri Net plot made liveness and estimated time is obtained if production starts at 06.00, it will end at 00.10

Keywords: max-plus algebra, petri net, soyghurt production

\section{PENDAHULUAN}

Pada era modernisasi ini teknologi dan ilmu pengetahuan semakin berkembang pesat sehingga banyak mempengaruhi kehidupan manusia. Perkembangan teknologi dan ilmu pengetahuan telah banyak merubah pola pikir dan perilaku masyarakat menjadi lebih maju dan memiliki daya saing untuk mempertahankan hidup. Salah satu dampak dari era modernisasi ini adalah teknologi pangan yang semakin berkembang dan menghasilkan banyak produk olahan makanan seperti soyghurt.

Soyghurt merupakan fermentasi susu kedelai oleh dua bakteri yaitu bakteri L. Bulgaricus dan bakteri $S$. Themophilus menurut Purwati (2008:134). Pembuatan soyghurt merupakan salah satu pemanfaatan bioteknogi pangan yang menerapkan bakteri yang aman dan dapat dikonsumsi oleh manusia. Soyghurt memiliki banyak manfaat untuk kesehatan tubuh terutama pada sistem pencernaan manusia, dan masih banyak manfaat lainnya. Proses pembuatan soyghurt hampir sama dengan pembuatan yoghurt yang sama-sama menggunakan susu sebagai media utamanya namun terdapat perbedaan jenis susu yang akan dijadikan medianya. Soyghurt merupakan alternatif makanan atau minuman bagi masyarakat yang mengalami alergi susu sapi atau yang sedang diet protein hewani. Pembuatan soyghurt masih tergolong baru yang sedang dikembangkan oleh beberapa orang di Indonesia salah satunya yaitu industri rumahan skala kecil yang sedang ditekuni oleh Bapak Sukasno. Peluang usaha yang sedang dikembangkan oleh Bapak Sukasno ini memanfaatkan soyghurt untuk pembuatan minuman soyghurt yang memiliki varians rasa dan soyghurt plain untuk bahan dasar pembuatan salad buah dan minuman soyghurt dengan variasi rasa. Namun terdapat kendala pada saat proses pembuatan soyghurt ini yaitu masalah estimasi waktu pembuatan soyghurt dari proses awal hingga proses akhir. Penerapan ilmu matematika seperti Aljabar Max-plus dan Petri Net dapat diterapkan pada usaha rumah produksi soyghurt dalam memodelkan matematika dan mengestimasi lamanya waktu pembuatan dari awal sampai akhir.

Petri Net dan Aljabar Max-plus merupakan salah satu bidang matematika yang memiliki banyak peranan dalam membantu memodelkan dan menjadwalkan sistem transportasi, produksi, sistem pendaftaran ujian akhir semester seperti yang dilakukan oleh Nurmalitasari (2018:47) dan sebagainya. Petri net dan aljabar max-plus memiliki hubungan dalam memodelkan matematika pada 
permasalahan-permasalahan sehari-hari seperti pada bidang produksi yaitu pada sistem produksi gelas pada penelitian Pramesthi (2017:225), produksi meubel rotan pada penelitian Rafflesia (2012:775), dan pada produksi soyghurt. Petri Net digunakan dalam penentuan alur pembuatan soyghurt dan Aljabar Max-plus digunakan untuk mengestimasi waktu yang diperlukan untuk membuat soyghurt dari proses awal sampai menjadi soyghurt, Sehingga penulis tertarik untuk melakukan penelitian yang berjudul "Penerapan Aljabar Max-plus dan Petri Net Pada Pembuatan Soyghurt".

\section{METODE}

Jenis penelitian ini adalah penelitian terapan yang bertujuan memcahkan masalah-masalah kehidupan praktis menurut Sugiyono (2016). Teknik pengumpulan data yaitu observasi dan wawancara. Sumber data yang diperoleh yaitu data sekunder.

Langkah-langkah yang dilakukan dalam penelitian ini adalah sebagai berikut:

1. Studi Literatur

Pada tahap ini diawali dengan mempelajari referensi penunjang penelitian baik teori Aljabar Max-Plus dan Petri Net yang didapat dari bukubuku literatur, jurnal ilmiah.

2. Mengumpulkan data

Pada tahap ini dilakukan pengumpulan data sekunder yang diperlukan seperti data proses produksi soyghurt beserta waktu pada setiap tahapan produksi.

3. Menyusun Alur Petri Net

Pada tahap ini akan dilakukan penyusunan alur Petri Net dari data yang telah diperoleh sebelumnya yaitu data proses produksi soyghurt

4. Membuat model Aljabar Max Plus.

Pada tahap ini membuat modelproses produksi soyghurt menggunakan model Aljabar Max Plus

5. Simulasi dan hasil

Pada tahap ini, model proses produksi soyghurt yang telah diperoleh kemudian disimulasikan menggunakan perangkat lunak Pipe dan software Scilab 5.4.0 oleh Subiono (2015) sehingga memperoleh penjadwalan waktu sehingga lebih lanjut akan dapat memperoleh berapa waktu proses pembuatan soyghurt.

\section{HASIL DAN PEMBAHASAN}

langkah-langkah pembuatan soyghurt, yaitu: 1) susu kedelai ditambahkan gula dan bubuk skim 2) susu kedelai dipasteurisasi $\left(85^{\circ} \mathrm{C}\right)$ selama 30 menit, 3) susu kedelai didinginkan sampai suhu mencapai $\left.\left(45{ }^{\circ} \mathrm{C}\right), 4\right)$ susu kedelai diinokulasi dengan starter (Lactobacillus bulgaricus dan Streptococcus thermophilus) selama 48 jam, 4) kemudian disaring untuk menghasilkan dua produk yaitu bibit kefir, dan produk soyghurt, 5) soyghurt yang telah jadi dimasukkan ke dalam wadah atau botol, 6) soyghurt yang telah dimasukkan ke dalam botol kemudian diinokulasi dengan suhu $\left(45^{\circ} \mathrm{C}\right)$ selama 4 sampai 6 jam, 7) kemudian dilakukan pengamatan terhadap soyghurt yang terbentuk, jika terjadi penggumpalan disertai pemisahan cairan dan gumpalan serta terbentuk gas, maka soyghurt telah terkontaminasi oleh bakteri lain sehingga terjadi gas yang mengendap di dalam botol soyghurt dan dengan demikian proses pembuatan soyghurt dikatakan gagal, jika tidak maka dikatakan berhasil, 8) soyghurt siap dikonsumsi.

\section{Petri Net Pada Pembuatan Soyghurt}

Pada alur pembuatan soyghurt dapat dibuat alur petri net yang memuat variable transisi dan place. Pada pemodelan Petri Net ini bobot yang digunakan yaitu lamanya waktu yang dibutuhkan setiap proses produksi soyghurt. Berikut alur Petri Net sistem produksi soyghurt yang direpresentasikan melalui software PIPE 4.3.0.

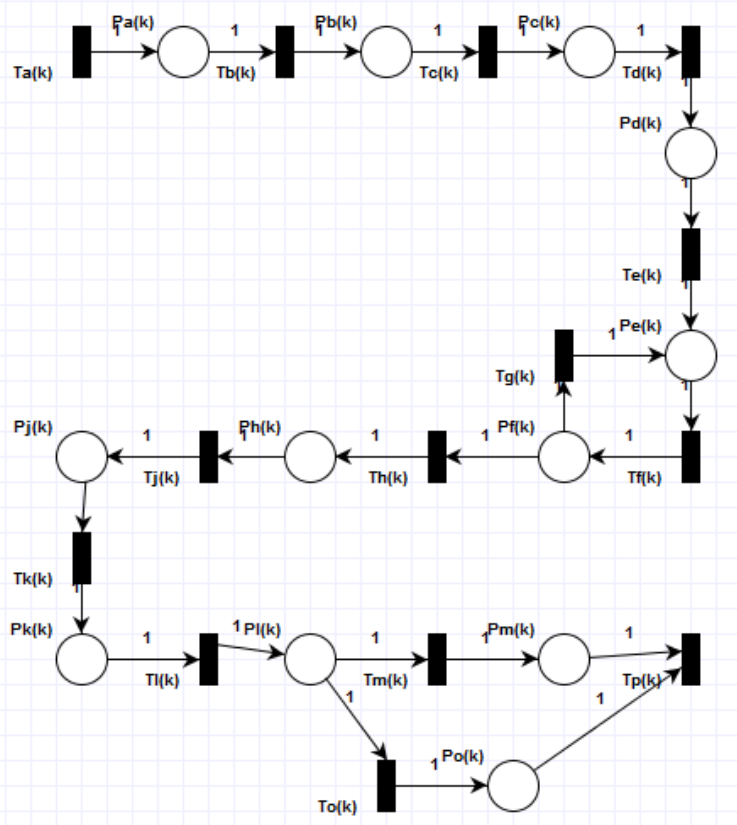

Gambar 1. Diagram Petri Net Soyghurt Pada Saat Ke$\mathbf{k}$

Berikut ini disajikan keterangan variabel-variabel yang menunjukkan waktu, sebagai berikut:

Kemudian tabel matriks forward, matriks backward, dan matriks kombinasi dibuat matriks seperti berikut:

Himpunan Transisi

$T_{a}(k)=$ Mulai saat ke- $k$

$T_{b}(k)=$ Proses penambahan gula dan susu bubuk skim ke dalam susu kedelai saat ke- $k$

$T_{c}(k)=$ Proses susu kedelai dipasteurisasi $\left(85^{0} \mathrm{C}\right)$ saat ke- $k$ 
$T_{d}(k)=$ Proses pendinginan susu kedelai sampai $\left(45^{0} \mathrm{C}\right)$ saat ke- $k$

$T_{e}(k)=$ Proses diinokulasi dengan starter (Lactobacillus bulgaricus dan Streptococcus thermophilus) saat ke- $k$

$T_{f}(k)=$ Proses penyaringan saat ke- $k$

$T_{g}(k)=$ Proses menjadi bibit kefir saat ke- $k$

$T_{h}(k)=$ Proses menjadi produk soyghurt saat ke- $k$

$T_{j}(k)=$ Proses soyghurt dimasukkan ke dalam botol saat ke- $k$

$T_{k}(k)=$ Proses inokulasi dengan suhu $\left(45^{\circ} \mathrm{C}\right)$ saat ke- $k$

$T_{l}(k)=$ Proses pengamatan saat ke- $k$

$T_{m}(k)=$ Sesuai saat ke- $k$

$T_{0}(k)=$ Tidak sesuai saat ke- $k$

$T_{p}(k)=$ Selesai saat ke- $k$

$I^{+}$

$=\left(\begin{array}{llllllllllllll}1 & 0 & 0 & 0 & 0 & 0 & 0 & 0 & 0 & 0 & 0 & 0 & 0 & 0 \\ 0 & 1 & 0 & 0 & 0 & 0 & 0 & 0 & 0 & 0 & 0 & 0 & 0 & 0 \\ 0 & 0 & 1 & 0 & 0 & 0 & 0 & 0 & 0 & 0 & 0 & 0 & 0 & 0 \\ 0 & 0 & 0 & 1 & 0 & 0 & 0 & 0 & 0 & 0 & 0 & 0 & 0 & 0 \\ 0 & 0 & 0 & 0 & 1 & 0 & 1 & 0 & 0 & 0 & 0 & 0 & 0 & 0 \\ 0 & 0 & 0 & 0 & 0 & 1 & 0 & 0 & 0 & 0 & 0 & 0 & 0 & 0 \\ 0 & 0 & 0 & 0 & 0 & 0 & 0 & 1 & 0 & 0 & 0 & 0 & 0 & 0 \\ 0 & 0 & 0 & 0 & 0 & 0 & 0 & 0 & 1 & 0 & 0 & 0 & 0 & 0 \\ 0 & 0 & 0 & 0 & 0 & 0 & 0 & 0 & 0 & 1 & 0 & 0 & 0 & 0 \\ 0 & 0 & 0 & 0 & 0 & 0 & 0 & 0 & 0 & 0 & 1 & 0 & 0 & 0 \\ 0 & 0 & 0 & 0 & 0 & 0 & 0 & 0 & 0 & 0 & 0 & 1 & 0 & 0 \\ 0 & 0 & 0 & 0 & 0 & 0 & 0 & 0 & 0 & 0 & 0 & 0 & 1 & 0\end{array}\right)$ $I^{-}$

$=\left(\begin{array}{llllllllllllll}0 & 1 & 0 & 0 & 0 & 0 & 0 & 0 & 0 & 0 & 0 & 0 & 0 & 0 \\ 0 & 0 & 1 & 0 & 0 & 0 & 0 & 0 & 0 & 0 & 0 & 0 & 0 & 0 \\ 0 & 0 & 0 & 1 & 0 & 0 & 0 & 0 & 0 & 0 & 0 & 0 & 0 & 0 \\ 0 & 0 & 0 & 0 & 1 & 0 & 0 & 0 & 0 & 0 & 0 & 0 & 0 & 0 \\ 0 & 0 & 0 & 0 & 0 & 1 & 0 & 0 & 0 & 0 & 0 & 0 & 0 & 0 \\ 0 & 0 & 0 & 0 & 0 & 0 & 1 & 1 & 0 & 0 & 0 & 0 & 0 & 0 \\ 0 & 0 & 0 & 0 & 0 & 0 & 0 & 0 & 1 & 0 & 0 & 0 & 0 & 0 \\ 0 & 0 & 0 & 0 & 0 & 0 & 0 & 0 & 0 & 1 & 0 & 0 & 0 & 0 \\ 0 & 0 & 0 & 0 & 0 & 0 & 0 & 0 & 0 & 0 & 1 & 0 & 0 & 0 \\ 0 & 0 & 0 & 0 & 0 & 0 & 0 & 0 & 0 & 0 & 0 & 1 & 1 & 0 \\ 0 & 0 & 0 & 0 & 0 & 0 & 0 & 0 & 0 & 0 & 0 & 0 & 0 & 1 \\ 0 & 0 & 0 & 0 & 0 & 0 & 0 & 0 & 0 & 0 & 0 & 0 & 0 & 1\end{array}\right)$

IO

$=\left(\begin{array}{ccccccccccccc}1 & -1 & 0 & 0 & 0 & 0 & 0 & 0 & 0 & 0 & 0 & 0 & 0 \\ 0 & 1 & -1 & 0 & 0 & 0 & 0 & 0 & 0 & 0 & 0 & 0 & 0 \\ 0 & 0 & 1 & -1 & 0 & 0 & 0 & 0 & 0 & 0 & 0 & 0 & 0 \\ 0 & 0 & 0 & 1 & -1 & 0 & 0 & 0 & 0 & 0 & 0 & 0 & 0 \\ 0 & 0 & 0 & 0 & 1 & -1 & 0 & 0 & 0 & 0 & 0 & 0 & 0 \\ 0 & 0 & 0 & 0 & 0 & 1 & -1 & -1 & 0 & 0 & 0 & 0 & 0 \\ 0 & 0 & 0 & 0 & 0 & 0 & 0 & 1 & -1 & 0 & 0 & 0 & 0 \\ 0 & 0 & 0 & 0 & 0 & 0 & 0 & 0 & 1 & -1 & 0 & 0 & 0 \\ 0 & 0 & 0 & 0 & 0 & 0 & 0 & 0 & 0 & 1 & -1 & 0 & 0 \\ 0 & 0 & 0 & 0 & 0 & 0 & 0 & 0 & 0 & 0 & 1 & -1 & -1 \\ 0 & 0 & 0 & 0 & 0 & 0 & 0 & 0 & 0 & 0 & 0 & 1 & 0 \\ 0 & 0 & 0 & 0 & 0 & 0 & 0 & 0 & 0 & 0 & 0 & 0 & 1\end{array}\right.$

Diberikan keadaan awal dari model Petri Net yang telah dibuat yaitu
Dimana

$$
x_{0}{ }^{*}=\left(\begin{array}{llllllllllll}
0 & 0 & 0 & 0 & 0 & 0 & 0 & 0 & 0 & 0 & 0 & 0
\end{array}\right)^{t}
$$

$$
x_{0}{ }^{*}=\left(P_{0} P_{1} P_{2} P_{3} P_{4} P_{5} P_{6} P_{7} P_{8} P_{9} P_{10} P_{11} P_{12}\right)^{t}
$$

Ketika $T_{0}$ enable dan dapat difire, didapatkan nilai $x_{0}=$ $x_{0}{ }^{*}+I O u_{1}$, dimana nilai $u_{1}$ adalah kolom pertama dari matriks identitas. Jika perhitungan tersebut dilakukan berulang-ulang, maka akan didapatkan hubungan sebagai berikut ini yang disajikan dalam coverability tree. Dapat dilihat bahwa nilai matriks tidak pernah menjadi matriks nol, demikian dapat disimpulkan bahwa alur Petri Net yang dibuat tidak deadlock dikarenakan setiap matriks kolom dari himpunan transisi tidak ada yang bernilai matriks nol dan terjadi looping.

Variabel-variabel tersebut digunakan untuk membentuk model aljabar Max Plus yang disajikan sebagai berikut:

$$
T_{a}(k)=v_{T_{a}, k} \otimes T_{a}(k-1)
$$

$T_{b}(k)=v_{T_{b}, k} \otimes T_{a}(k)$

$=v_{T_{b}, k} \otimes\left(v_{T_{a}, k} \otimes T_{a}(k-1)\right)$

$=v_{T_{b}, k} \otimes v_{T_{a}, k} \otimes T_{a}(k-1)$

$T_{c}(k)=v_{T_{c}, k} \otimes T_{b}(k)$

$$
=v_{T_{c}, k} \otimes\left(v_{T_{b}, k} \otimes v_{T_{a}, k} \otimes T_{a}(k-1)\right)
$$$$
=v_{T_{c}, k} \otimes v_{T_{b}, k} \otimes v_{T_{a}, k} \otimes T_{a}(k-1)
$$

$T_{d}(k)=v_{T_{d}, k} \otimes T_{c}(k)$ $=v_{T_{d}, k} \otimes\left(v_{T_{c}, k} \otimes v_{T_{b}, k} \otimes v_{T_{a}, k} \otimes T_{a}(k-1)\right)$ $=v_{T_{d}, k} \otimes v_{T_{c}, k} \otimes v_{T_{b}, k} \otimes v_{T_{a}, k} \otimes T_{a}(k-1)$

$T_{e}(k)=v_{T_{e}, k} \otimes T_{d}(k)$ $=v_{T_{e}, k} \otimes\left(v_{T_{d}, k} \otimes v_{T_{c}, k} \otimes v_{T_{b}, k} \otimes v_{T_{a}, k} \otimes T_{a}(k-1)\right)$ $=v_{T_{e}, k} \otimes v_{T_{d}, k} \otimes v_{T_{c}, k} \otimes v_{T_{b}, k} \otimes v_{T_{a}, k} \otimes T_{a}(k-1)$

$T_{f}(k)=v_{T_{f}, k} \otimes\left(T_{e}(k) \oplus T_{g}(k-1)\right)$ $=\left(v_{T_{f}, k} \otimes T_{e}(k)\right) \oplus\left(v_{T_{f}, k} \otimes T_{g}(k-1)\right)$ $=\left(v_{T_{f}, k} \otimes v_{T_{e}, k} \otimes v_{T_{d}, k} \otimes v_{T_{c}, k} \otimes v_{T_{b}, k} \otimes v_{T_{a}, k} \otimes T_{a}(k\right.$ $-1)) \oplus\left(v_{T_{f}, k} \otimes T_{g}(k-1)\right)$

$T_{g}(k)=v_{T_{g}, k} \otimes T_{f}(k)$

$T_{h}(k)=v_{T_{h}, k} \otimes T_{f}(k)$

$T_{j}(k)=v_{T_{j}, k} \otimes T_{h}(k)$

$\Phi_{k} \gamma_{k)}=v_{T_{k}, k} \otimes T_{j}(k)$

$\tilde{\Phi}_{l}(k)=v_{T_{l}, k} \otimes T_{k}(k)$

$q_{m}(k)=v_{T_{m}, k} \otimes T_{l}(k)$

$q_{0}(k)=v_{o, k} \otimes T_{l}(k)$

$\Phi_{p}(k)=v_{p, k} \otimes\left(T_{o}(k) \oplus T_{m}(k)\right)$

Selanjutnya misalkan diberikan lamanya waktu proses tdalam menit) tiap tahap maka akan diperoleh hasil sebagai berikut ini:

$$
\begin{array}{ll}
v_{T_{a}, k}=10 & v_{T_{b}, k}=20 \\
v_{T_{c}, k}=20 & v_{T_{d}, k}=10
\end{array}
$$




$$
\begin{array}{cc}
v_{T_{e}, k}=10 & v_{T_{f}, k}=5 \\
v_{T_{g}, k}=960 & v_{T_{h}, k}=960 \\
v_{T_{j}, k}=30 & v_{T_{k}, k}=10 \\
v_{T_{l}, k}=5 & v_{T_{m}, k}=10 \\
v_{T_{o}, k}=10 & v_{T_{p}, k}=5
\end{array}
$$

Dengan keadaaan awal $k=0$, didapatkan:

$$
\left(\begin{array}{c}
T_{a}(k) \\
T_{b}(k) \\
T_{c}(k) \\
T_{d}(k) \\
T_{e}(k) \\
T_{f}(k) \\
T_{g}(k) \\
T_{h}(k) \\
T_{j}(k) \\
T_{k}(k) \\
T_{l}(k) \\
T_{m}(k) \\
T_{o}(k)
\end{array}\right)=\left(\begin{array}{l}
0 \\
0 \\
0 \\
0 \\
0 \\
0 \\
0 \\
0 \\
0
\end{array}\right)
$$

Sehingga didapatkan

$$
\left(\begin{array}{c}
T_{a}(1) \\
T_{b}(1) \\
T_{c}(1) \\
T_{d}(1) \\
T_{e}(1) \\
T_{f}(1) \\
T_{g}(1) \\
T_{h}(1) \\
T_{j}(1) \\
T_{k}(1) \\
T_{l}(1) \\
T_{m}(1) \\
T_{o}(1)
\end{array}\right)=
$$$$
\left(\begin{array}{ccccccc}
10 & \infty & \infty & \infty & \infty & \infty & \infty \\
30 & \infty & \infty & \infty & \infty & \infty & \infty \\
50 & \infty & \infty & \infty & \infty & \infty & \infty \\
60 & \infty & \infty & \infty & \infty & \infty & \infty \\
70 & \infty & \infty & \infty & \infty & \infty & \infty \\
75 & \infty & \infty & \infty & \infty & \infty & 5 \\
1035 & \infty & \infty & \infty & \infty & \infty & 965 \\
1035 & \infty & \infty & \infty & \infty & \infty & 965 \\
1065 & \infty & \infty & \infty & \infty & \infty & 995 \\
1075 & \infty & \infty & \infty & \infty & \infty & 1005 \\
1080 & \infty & \infty & \infty & \infty & \infty & 1010 \\
1090 & \infty & \infty & \infty & \infty & \infty & 1020 \\
1090 & \infty & \infty & \infty & \infty & \infty & 1020
\end{array}\right.
$$

$\left.\begin{array}{llllll}\infty & \infty & \infty & \infty & \infty & \infty \\ \infty & \infty & \infty & \infty & \infty & \infty \\ \infty & \infty & \infty & \infty & \infty & \infty \\ \infty & \infty & \infty & \infty & \infty & \infty \\ \infty & \infty & \infty & \infty & \infty & \infty \\ \infty & \infty & \infty & \infty & \infty & \infty \\ \infty & \infty & \infty & \infty & \infty & \infty \\ \infty & \infty & \infty & \infty & \infty & \infty \\ \infty & \infty & \infty & \infty & \infty & \infty \\ \infty & \infty & \infty & \infty & \infty & \infty \\ \infty & \infty & \infty & \infty & \infty & \infty \\ \infty & \infty & \infty & \infty & \infty & \infty \\ \infty & \infty & \infty & \infty & \infty & \infty\end{array}\right)$

$\otimes\left(\begin{array}{l}0 \\ 0 \\ 0 \\ 0 \\ 0 \\ 0 \\ 0 \\ 0 \\ 0 \\ 0 \\ 0 \\ 0 \\ 0\end{array}\right)=\left(\begin{array}{c}10 \\ 30 \\ 50 \\ 60 \\ 70 \\ 75 \\ 1035 \\ 1035 \\ 1065 \\ 1075 \\ 1080 \\ 1090 \\ 1090\end{array}\right)$

Berdasarkan hasil perhitungan tersebut dapat diperoleh bahwa jika awal proses produksi akan dimulai pada jam 06.00, waktu memulai proses pertama yaitu 06.10, waktu penambahan gula, susu bubuk skim ke dalam susu kedelai saat pertama yaitu 06.30, waktu saat susu kedelai dipasteurisasi yaitu 06.50 , waktu pendinginan susu kedelai yaitu 07.00, waktu proses inokulasi starter bakteri yaitu 07.10, waktu proses penyaringan yaitu 07.15, waktu menjadi bibit kefir yaitu 23.15, dan proses selesai produksi yaitu 00.10 .

\section{Ucapan Terima Kasih}

Penulis mengucapkan terima kasih kepada Direktorat Riset dan Pengabdian Masyarakat Direktorat Jenderal Penguatan Riset dan Pengembangan Kementrian Riset, Teknologi, dan Pendidikan Tinggi atas bantuan biaya pada skim penelitian Hibah Penelitian Dosen Pemula (PDP) Tahun 2019.

\section{PENUTUP}

\section{Simpulan}

Dari alur Petri Net yang dibuat, nilai matriks tidak pernah menjadi matriks nol, demikian dapat disimpulkan bahwa alur Petri Net yang dibuat tidak deadlock dikarenakan setiap matriks kolom dari himpunan transisi tidak ada yang bernilai matriks nol dan terjadi looping, dan hasil perhitungan tersebut dapat diperoleh bahwa jika awal proses produksi akan dimulai pada jam 06.00, waktu memulai proses pertama yaitu 06.10, waktu penambahan gula, susu bubuk skim ke dalam susu kedelai saat pertama yaitu 06.30, waktu saat susu kedelai dipasteurisasi yaitu 06.50, waktu pendinginan susu kedelai yaitu 07.00, waktu proses inokulasi starter bakteri yaitu 07.10, waktu proses penyaringan yaitu 07.15 , waktu menjadi bibit kefir yaitu 23.15, dan proses selesai produksi yaitu 00.10.

\section{Saran}

Penelitian dapat diterapkan ke dalam bidang lain seperti bidang industri, keuangan dan sebagainya. 
Buana Matematika: Jurnal Ilmiah Matematika dan Pendidikan Matematika Volume 9, Nomor 2, Tahun 2019

\section{DAFTAR PUSTAKA}

Nurmalitasari, Dewi., \& Rayungsari, Maya.(2018).Model Aljabar Max Plus dan Petri Net Pada Sistem Pelayanan Pendaftaran Ujian Akhir Semester. Jurnal Aksioma, 9(2), 47-56. https://dx.doi.org/10.26877/aks.v9i2.299.

Pramesthi, Sri Rejeki Puri Wahyu. (2017). Terapan Aljabar Max-Plus Pada Sistem Proses Produksi Gelas. Jurnal Widyaloka, 4(2), 223-239.

Purwathi, Henny, dkk. (2008). Pengaruh Waktu Simpan Terhadap Kualitas Soyghurt Dengan Penambahan Susu Bubuk. Jurnal Widya Teknik, 7(2), 134-143.

Rafflesia, Ulfasari. (2012). Penerapan Aljabar Max-Plus Pada Sistem Produksi Meubel Rotan. Jurnal Gradien, 8(1), $77-779$.

Subiono. (2015). Aljabar Min-Max Plus Dan Terapannya. Buku Ajar Mata Kuliah Pilihan Pasca Sarjana Matematika, 1-165. Surabaya: Institut Teknologi Sepuluh Nopember.

Sugiyono. (2016). Metode Penelitian Kuantitatif, Kualitatif, dan R\&D. Bandung: PT Alfabet. 
Dewi Nurmalitasari ${ }^{1 *}$, Ratna Eka Iswahyuni²: Desain Petri Net dan Aljabar Max-Plus pada Sistem Produksi Soyghurt Susu Berkah

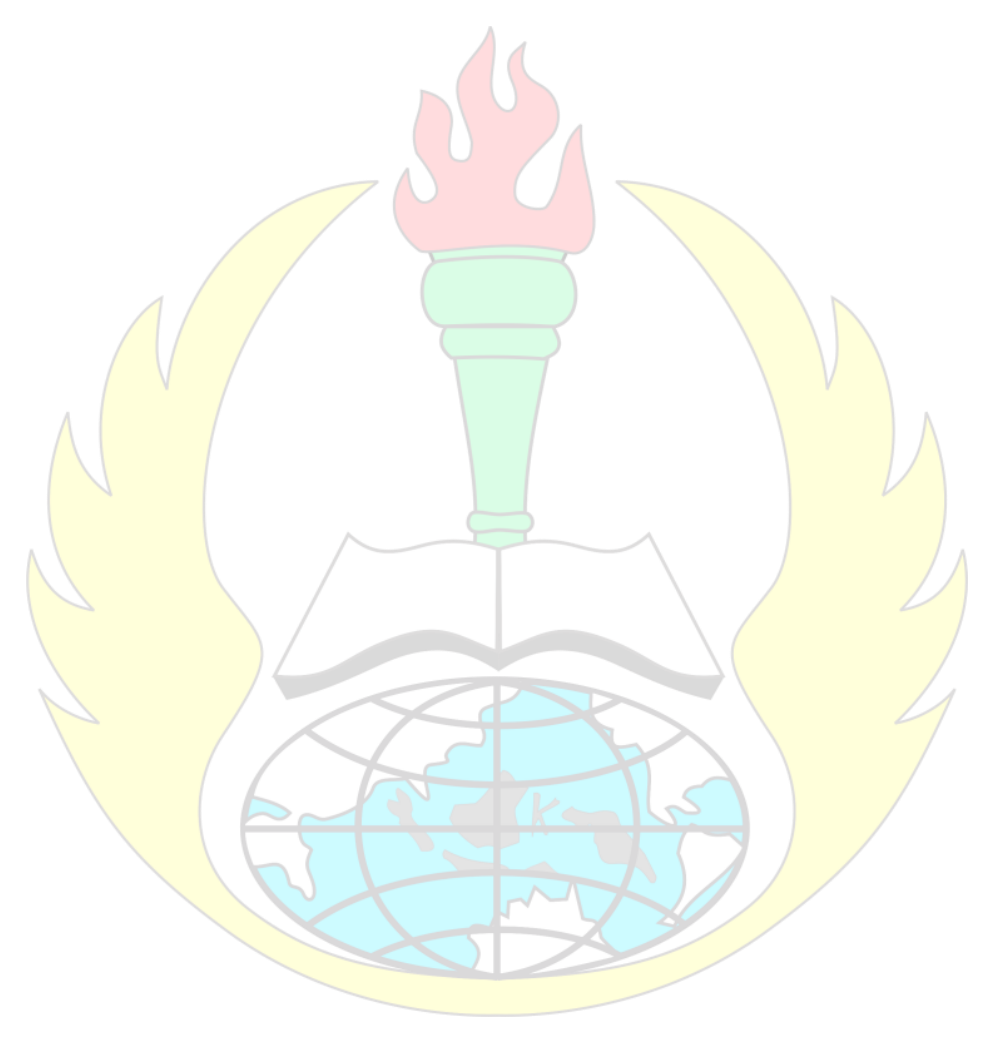

